\title{
Effect of Nitrogen, Phosphorus and Sulphur on Yield, Nutrient Uptake and Soil Fertility after Harvest of Mustard (Brassica juncea L.)
}

\author{
Zalak Y. Chauhan ${ }^{1 *}$, D. K. Patel ${ }^{2}$ and Komal Bhabhor ${ }^{3}$ \\ ${ }^{1}$ Department of Agronomy, C. P. College of Agriculture, \\ SDAU, Sardarkrushinagar-385506, India \\ ${ }^{2}$ State Council of Agricultural Universities, Gandhinagar, India \\ ${ }^{3}$ Department of soil science and agricultural chemistry, \\ C. P. College of Agriculture, SDAU, Sardarkrushinagar-385506, India
}

\section{A B S T R A C T}

\begin{tabular}{l} 
K e y w o r d s \\
Mustard, Nitrogen, \\
sulphur, Seed yield, \\
Nutrient content, \\
Nutrient uptake, \\
Soil fertility \\
\hline Article Info \\
\hline $\begin{array}{l}\text { Accepted: } \\
\text { 26 May 2020 } \\
\text { Available Online: } \\
\text { 10 June } 2020\end{array}$ \\
\hline
\end{tabular}

\section{Keywords}

Mustard, Nitrogen, sulphur, Seed yield Nutrient content, Soil fertility
A field experiment was carried out at Agronomy Instructional Farm, C.P. College of Agriculture, Sardarkrushinagar Dantiwada Agricultural University, Sardarkrushinagar, Gujarat during rabi season of the year 2018-19 to study the effect of different fertility levels on yield, nutrient uptake and soil fertility after harvest of mustard. The experiment comprising of twelve treatment combinations viz., three levels of nitrogen $(50,75$ and $100 \mathrm{~kg} \mathrm{~N} / \mathrm{ha}$ ), two levels of phosphorus (50 and $75 \mathrm{~kg} \mathrm{P}_{2} \mathrm{O}_{5} / \mathrm{ha}$ ) and two levels of sulphur (40 and $60 \mathrm{~kg} \mathrm{~S} / \mathrm{ha}$ ) were evaluated in randomized block design with factorial concept and three replications. The soil of the experimental field was loamy sand in texture, low in organic carbon $(0.18 \%)$ and available nitrogen $(171 \mathrm{~kg} / \mathrm{ha})$, medium in available $\mathrm{P}_{2} \mathrm{O}_{5}$ $(37.2 \mathrm{~kg} / \mathrm{ha})$ and low in available sulphur $(6.8 \mathrm{~kg} / \mathrm{ha})$ with soil $\mathrm{pH}$ of 7.3 . Results revealed that higher yield, nutrient content and uptake of nutrient of mustard and higher available nutrient status in soil can be secured by the application of $75 \mathrm{~kg}$ N/ha along with $50 \mathrm{~kg}$ $\mathrm{P}_{2} \mathrm{O}_{5} /$ ha and $40 \mathrm{~kg}$ S/ha in loamy sand soil of North Gujarat Agro-climatic conditions.

\section{Introduction}

Oilseed crops occupy an important place in Indian agricultural economy as well as in human life. They are not only rich sources of energy and carriers of fat soluble vitamins 'A,' $D$,' $E$ ' and ' $K$ ' but they form the ingredients of foods and flavours; cosmetics and condiments; soap and detergents; lubricants and laxatives and also known for their medical and therapeutic use. Rapeseed- mustard is the third most important edible oilseed crop in India having 30 to 48 per cent oil content after soybean and groundnut.

Mustard seed has 28 to 36 per cent protein content with a high nutritive value. Mustard is one of the major sources of oil in India. Indian mustard [Brassica juncea (L.) Czern \& Coss.] is the most important rabi season oilseed crop, which thrives best in light to heavy loam soil in areas having 25 to $40 \mathrm{~cm}$ 
rainfall. Mustard oil is mainly used for cooking, frying and in pickles. Oil is also used in preparing vegetable ghee, hair oil, medicines, soaps, lubricating oil and in tanning industries. The oil cake left after extraction is utilized as cattle feed and manure. Its oil cake contains 5.2, 1.8 and 1.2 per cent $\mathrm{N}, \mathrm{P}$ and $\mathrm{K}$, respectively. The green tender plant is used for preparing vegetable commonly called "Sarsonkasaag". The whole seed is used in preparing pickle and flavouring vegetable and curries.

Worldwide, India is the fourth largest mustard producer. The mustard yield can be increased to 2 to 2.5 t/ha by adopting the improved agronomic practices. Fertilizer management plays an important role for increasing the productivity of mustard, which can be realized by providing plant nutrients in required amount along with its suitable application during crop growth period. The chemical fertilizers being used for supplementing the major nutrient are generally either deficient or low in sulphur content. The importance of sulphur fertilization for increasing yield and quality of Indian mustard is being increasingly recognized. However, the information regarding optimum level of sulphur and its influences on seed yield and quality of mustard is meager. Probably for these reasons, mustard crop needs comparatively higher amount of sulphur for proper growth and development and higher yields.

\section{Materials and Methods}

The experiment was conducted at the Agronomy Instructional Farm, Chimanbhai Patel College of Agriculture, Sardarkrushinagar Dantiwada Agricultural University, Sardarkrushinagar, Gujarat during rabi season of the year 2018-19. The soil of the experimental field was loamy sand in texture, low in organic carbon $(0.18 \%)$ and available nitrogen (171 kg/ha), medium in available $\mathrm{P}_{2} \mathrm{O}_{5}(37.2 \mathrm{~kg} / \mathrm{ha})$ and low in available sulphur $(6.8 \mathrm{~kg} / \mathrm{ha})$ with soil $\mathrm{pH}$ of 7.3. There were twelve treatment combinations consisting of three levels of nitrogen (50, 75 and $100 \mathrm{~kg} \mathrm{~N} / \mathrm{ha})$, two levels of phosphorus (50 and $75 \mathrm{~kg} \mathrm{P}_{2} \mathrm{O}_{5} / \mathrm{ha}$ ) and two levels of sulphur (40 and $60 \mathrm{~kg} \mathrm{~S} / \mathrm{ha}$ ) evaluated in randomized block design with factorial concept and three replications. The seeds of mustard variety GDM-4 were sown manually on October 30, 2018 by maintaining $45 \mathrm{~cm} \times 15 \mathrm{~cm}$ distance between two rows and two plants at a depth of $3 \mathrm{~cm}$ in previously opened furrows using seed rate of $3.75 \mathrm{~kg} / \mathrm{ha}$. The experimental plots were fertilized as per treatments. Nitrogen, phosphorus and sulphur were applied as per the treatment through urea, DAP and gypsum, respectively. The total quantity of phosphorus, gypsum and half dose of nitrogen were applied in opened furrow at the time of sowing as per treatments. The remaining half dose of nitrogen was top dressed at 30 days after sowing at the time of third irrigation. Recommended practices of the region were followed for raising the crop. The observations recorded for growth and yield attributes, yield and quality parameters were put to the statistical analysis in accordance with analysis of variation techniques as suggested by Fisher (1950) for randomized block design (RBD) with factorial concept.

\section{Results and Discussion}

\section{Effect of nitrogen}

Perusal of data presented in Table 1 indicated that application of $100 \mathrm{~kg} \mathrm{~N} / \mathrm{ha}\left(\mathrm{N}_{2}\right)$ reported significantly higher seed $(2485 \mathrm{~kg} / \mathrm{ha})$ and stover (5208 $\mathrm{kg} / \mathrm{ha}) . O n$ an average, the application of $100 \mathrm{~kg} \mathrm{~N} / \mathrm{ha}\left(\mathrm{N}_{3}\right)$ and $75 \mathrm{~kg}$ $\mathrm{N} / \mathrm{ha}\left(\mathrm{N}_{2}\right)$ increased seed yield to the tune of 15.6 and 10.8 per cent over the $50 \mathrm{~kg} \mathrm{~N} / \mathrm{ha}$ $\left(\mathrm{N}_{1}\right)$, respectively. Higher yield in these 
treatments might be due to cumulative effect of elevated growth structure as well as yield structure. Increase in seed yield was mainly because of remarkable improvement in growth and yield attributing characters and ultimately resulted from higher nitrogen levels that provide nutrition to the plant ultimately resulted in maximum seed yield and stover yield. This result was corroborated by Sah et al., (2006) and Dawson et al., (2009). Effect of nitrogen found significant on nitrogen content in seed $(3.28 \%)$ and Stover $(0.45 \%)$ by application of $100 \mathrm{~kg} \mathrm{~N} / \mathrm{ha}\left(\mathrm{N}_{2}\right)$, while phosphorus and sulphur content in seed and stover was found non- significant. Treatment $\mathrm{N}_{3} \quad(100 \mathrm{~kg} \quad \mathrm{~N} / \mathrm{ha})$ recorded significantly higher nitrogen (81.48 and 23.34 $\mathrm{kg} / \mathrm{ha}$ ), phosphorus (13.64 and $10.63 \mathrm{~kg} / \mathrm{ha}$ ) and sulphur (10.07 and $6.99 \mathrm{~kg} / \mathrm{ha})$ seed and stover uptake respectively. Significantly higher nitrogen content in seed and Stover might be due to relatively higher with increasing level of nitrogen. Since the concentration of nitrogen and dry matter production increased with nitrogen application, the uptake of nutrients also increases. The higher percentage of nitrogen was recorded in seed. It is because of the ability of nitrogen to more towards reproductive organs. Since most of nutrients $(\mathrm{N}, \mathrm{P}$ and $\mathrm{S}$ ) in seed is relocated from their reserves in vegetative parts, better nutritional conditions of soil with balanced fertilization seems to be on account of their higher concentration in plants. The positive effect of nitrogen on $\mathrm{P}$ content and uptake might be due to increase in the photosynthesis, which resulted into the accumulation of higher quantity of carbohydrates in the vegetative portion of the plants and ultimately enhancing the uptake of nutrients. It was confirmed with the finding of Ameta et al., (2014), Parmar et al., (2011) and Tripathi et al., (2011). Increased available $\mathrm{N}$ in soil $(180.93 \mathrm{~kg} / \mathrm{ha})$ with higher level of nitrogen treatment might be assign due to additional application of nitrogen in soil and non-significant effect of nitrogen on phosphorus and sulphur soil nutrient status. Increasing nutrient status of nitrogen in soil might be due to availability of applied nitrogen in soil

\section{Effect of phosphorus}

A perusal of data in Table 1 indicated that different levels of phosphorus failed to exert significant differences for biological yields, nitrogen and sulphur content and uptake from seed and stover. An application of phosphorus $75 \mathrm{~kg} \mathrm{P}_{2} \mathrm{O}_{5} /$ ha $\left(\mathrm{P}_{2}\right)$ was recorded significantly the maximum phosphorus content in seed $(0.60 \%)$ and stover $(0.21 \%)$ and phosphorus uptake by seed (14.37 kg/ha) and stover (10.56 kg/ha). Higher phosphorus content in seed and stover might be due to Phosphorus being responsible for synthesis of DNA and RNA and as an ingredient of phosphoproteins plays a central role in synthesis of proteins. Improvement in nutrient concentration in seed and stover due to $\mathrm{N}$ and $\mathrm{P}$. The considerable increase in $\mathrm{P}$ uptake by seed and stover could be attributed to the fact that $\mathrm{P}$ stimulates the early root development and growth and thereby efficient utilization of nutrients from the deeper soil layer.

A significant influence on these nutrient uptakes by seed and straw due to increase in concentration along with increase in yield of seed and stover. The results of investigation are in close agreement with those reported by, Jadav et al., (2016) and Singh and Thenua (2016). An application of phosphorus @ 75 $\mathrm{kg} \mathrm{P}_{2} \mathrm{O}_{5} / \mathrm{ha}\left(\mathrm{P}_{1}\right)$ recorded significantly higher available $\mathrm{P}_{2} \mathrm{O}_{5}(39.77 \mathrm{~kg} / \mathrm{ha})$ in the soil (Table $2)$. These might be due to enhanced microbial activity by $\mathrm{P}$ application in rhizosphere through development of fibrous and deep root system of plant there by recycled the nutrients from deeper layer to upper layer of soil. Similar results were observed by Trivedi et al., (2013) and Jadav et al., (2016). 
Table.1 Effect of fertility levels oncontent of nitrogen, phosphorus and sulphur in seed and stover of mustard under north Gujarat condition

\begin{tabular}{|c|c|c|c|c|c|c|c|c|c|c|c|c|c|c|}
\hline \multirow[t]{2}{*}{ Treatments } & \multirow[t]{2}{*}{$\begin{array}{c}\text { Seed } \\
\text { yield } \\
\text { (kg/ha) }\end{array}$} & \multirow[t]{2}{*}{$\begin{array}{c}\text { stover } \\
\text { yield } \\
\text { (kg/ha) }\end{array}$} & \multicolumn{2}{|c|}{$\begin{array}{c}\text { Nitrogen } \\
\text { content }(\%)\end{array}$} & \multicolumn{2}{|c|}{$\begin{array}{l}\text { Phosphorus } \\
\text { content }(\%)\end{array}$} & \multicolumn{2}{|c|}{$\begin{array}{c}\text { Sulphur } \\
\text { content } \\
(\%)\end{array}$} & \multicolumn{2}{|c|}{$\begin{array}{c}\text { Nitrogen } \\
\text { uptake } \\
\text { (kg/ha) }\end{array}$} & \multicolumn{2}{|c|}{$\begin{array}{c}\text { Phorsphorus } \\
\text { uptake (kg/ha) }\end{array}$} & \multicolumn{2}{|c|}{$\begin{array}{l}\text { Sulphur uptake } \\
\text { (kg/ha) }\end{array}$} \\
\hline & & & Seed & Stover & Seed & Stover & Seed & Stover & Seed & Stover & Seed & Stover & Seed & Stover \\
\hline \multicolumn{15}{|c|}{ Nitrogen levels(N) : } \\
\hline $\mathrm{N}_{0}: 50 \mathrm{~kg} / \mathrm{ha}$ & 2150 & 4634 & 3.07 & 0.39 & 0.539 & 0.194 & 0.392 & 0.128 & 65.99 & 17.90 & 11.67 & 9.00 & 8.42 & 5.93 \\
\hline $\mathrm{N}_{1}: 75 \mathrm{~kg} / \mathrm{ha}$ & 2382 & 5143 & 3.23 & 0.43 & 0.528 & 0.203 & 0.390 & 0.130 & 76.96 & 22.14 & 12.60 & 10.46 & 9.30 & 6.68 \\
\hline $\mathrm{N}_{2} 100 \mathrm{~kg} / \mathrm{ha}$ & 2485 & 5208 & 3.28 & 0.45 & 0.548 & 0.204 & 0.405 & 0.134 & 81.48 & 23.34 & 13.64 & 10.63 & 10.07 & 6.99 \\
\hline S.Em. \pm & 72 & 128 & 0.05 & 0.01 & 0.008 & 0.003 & 0.005 & 0.002 & 2.64 & 0.73 & 0.48 & 0.29 & 0.32 & 0.19 \\
\hline C.D. $(P=0.05)$ & 210 & 375 & 0.14 & 0.02 & NS & NS & NS & NS & 7.74 & 2.14 & 1.42 & 0.85 & 0.93 & 0.57 \\
\hline \multicolumn{15}{|c|}{ Phosphorus levels(P) : } \\
\hline$P_{0}: 50 \mathrm{~kg} / \mathrm{ha}$ & 2290 & 4880 & 3.17 & 0.42 & 0.475 & 0.195 & 0.392 & 0.130 & 72.73 & 20.37 & 10.90 & 9.50 & 8.99 & 6.34 \\
\hline$P_{1}: 75 \mathrm{~kg} / \mathrm{ha}$ & 2387 & 5110 & 3.21 & 0.43 & 0.601 & 0.206 & 0.399 & 0.131 & 76.89 & 21.89 & 14.37 & 10.56 & 9.53 & 6.72 \\
\hline S.Em. \pm & 59 & 104 & 0.04 & 0.01 & 0.006 & 0.003 & 0.004 & 0.002 & 2.16 & 0.60 & 0.39 & 0.24 & 0.26 & 0.16 \\
\hline C.D. $(P=0.05)$ & NS & NS & NS & NS & 0.019 & 0.008 & NS & NS & NS & NS & 1.16 & 1.02 & NS & NS \\
\hline \multicolumn{15}{|c|}{ Sulphur levels(S) : } \\
\hline$S_{0}: 40 \mathrm{~kg} / \mathrm{ha}$ & 2315 & 4902 & 3.14 & 0.42 & 0.534 & 0.199 & 0.383 & 0.199 & 72.95 & 20.46 & 12.43 & 9.76 & 8.89 & 6.23 \\
\hline$S_{1}: 60 \mathrm{~kg} / \mathrm{ha}$ & 2362 & 5088 & 3.24 & 0.43 & 0.542 & 0.202 & 0.408 & 0.202 & 76.66 & 21.80 & 12.84 & 10.30 & 9.64 & 6.83 \\
\hline S.Em.土 & 59 & 104 & 0.04 & 0.01 & 0.006 & 0.003 & 0.004 & 0.003 & 2.16 & 0.60 & 0.39 & 0.24 & 0.26 & 0.16 \\
\hline C.D. $(P=0.05)$ & NS & NS & NS & NS & NS & NS & 0.013 & NS & NS & $\mathbf{N S}$ & NS & NS & NS & 0.47 \\
\hline Interactions : & NS & NS & NS & NS & NS & NS & NS & NS & NS & NS & NS & NS & NS & NS \\
\hline C.V. (\%) & 10.62 & 8.86 & 5.23 & 5.72 & 5.07 & 5.82 & 4.79 & 4.95 & 12.23 & 11.96 & 13.24 & 9.98 & 11.91 & 10.31 \\
\hline
\end{tabular}


Table.2 Effect of fertility levels on available N, $\mathrm{P}_{2} \mathrm{O}_{5}$ and $\mathrm{S}$ status of soil after harvest of mustard under north Gujarat condition

\begin{tabular}{|c|c|c|c|}
\hline \multirow[t]{2}{*}{ Treatments } & \multicolumn{3}{|c|}{ Available nutrient status in soil } \\
\hline & $\mathbf{N}$ (kg/ha) & $\mathrm{P}_{2} \mathrm{O}_{5}$ (kg/ha) & $\mathrm{S}(\mathrm{mg} / \mathrm{kg})$ \\
\hline \multicolumn{4}{|c|}{ Nitrogen levels (kg/ha) } \\
\hline $\mathrm{N}_{0}: 50 \mathrm{~kg} / \mathrm{ha}$ & 173.81 & 38.26 & 7.59 \\
\hline $\mathrm{N}_{1}: 75 \mathrm{~kg} / \mathrm{ha}$ & 178.39 & 38.30 & 7.69 \\
\hline $\mathrm{N}_{2} 100 \mathrm{~kg} / \mathrm{ha}$ & 180.93 & 39.50 & 7.70 \\
\hline S.Em. \pm & 1.70 & 0.53 & 0.08 \\
\hline C.D. $(P=0.05)$ & 4.98 & NS & NS \\
\hline \multicolumn{4}{|l|}{ Phosphorus levels } \\
\hline$P_{0}: 50 \mathrm{~kg} / \mathrm{ha}$ & 176.97 & 37.60 & 7.62 \\
\hline$P_{1}: 75 \mathrm{~kg} / \mathrm{ha}$ & 178.45 & 39.77 & 7.71 \\
\hline S.Em. \pm & 1.39 & 0.43 & 0.07 \\
\hline C.D. $(P=0.05)$ & NS & 1.26 & NS \\
\hline \multicolumn{4}{|l|}{ Sulphur levels } \\
\hline$S_{0}: 40 \mathrm{~kg} / \mathrm{ha}$ & 176.02 & 38.47 & 7.49 \\
\hline$S_{1}: 60 \mathrm{~kg} / \mathrm{ha}$ & 179.40 & 38.91 & 7.83 \\
\hline S.Em. \pm & 1.39 & 0.43 & 0.07 \\
\hline C.D. $(P=0.05)$ & NS & NS & 0.20 \\
\hline Interactions : & NS & NS & NS \\
\hline C.V. (\%) & 3.31 & 4.72 & 3.69 \\
\hline
\end{tabular}




\section{Effect of sulphur}

A perusal of data in Table 1 indicated that different levels of sulphur had failed to exert their significant influence on yield of mustard. An application of sulphur $60 \mathrm{~kg} / \mathrm{ha}$ exerted its notable impact on increment of $\mathrm{S}$ content in seed $(0.41 \%)$. This was mainly due to greater availability of sulphur in soil, increased the $\mathrm{S}$ concentration. The increase in sulphur concentration was also reported by Neha et al., (2014) and Singh and Thenua (2016).

There was significant increase in sulphur uptake by stover with application of $60 \mathrm{~kg}$ $\mathrm{S} / \mathrm{ha}(6.83 \mathrm{~kg} / \mathrm{ha})$ over $40 \mathrm{~kg} \mathrm{~S} / \mathrm{ha}$. There was no significant increase in sulphur uptake by mustard seed.Increased uptake of sulphur by mustard with sulphur treatment might be assign due to increase in seed and stover yields and increase sulphur content of seed and stover which in term enhanced the uptake (Pachauri et al., (2012), Rai et al., (2014) and Singh and Thenua (2016).

An application of sulphur $60 \mathrm{~kg} / \mathrm{ha}\left(\mathrm{S}_{1}\right)$ registered significantly higher available $\mathrm{S}$ content $(7.83 \mathrm{mg} / \mathrm{kg})$ in soil. The increase in available nutrient status in soil with $S$ application might be due to stimulating effect of sulphur on mineralization of nutrients in soil and provide favorable condition for microbial activity as well as chemical activity, which resulted higher availability of nutrients ins oil (Jadav et al., (2016).

\section{Interaction effect}

The interaction effect of nitrogen, phosphorus and sulphur levels was not found significant on seed yield, nutrient content and uptake and available nutrients in soil after harvest.

From the ongoing results discussion it can be concluded that mustard crop should be fertilized with $75 \mathrm{~kg} \mathrm{~N} / \mathrm{ha}$ along with $50 \mathrm{~kg}$
$\mathrm{P}_{2} \mathrm{O}_{5} / \mathrm{ha}$ and $40 \mathrm{~kg} \mathrm{~S} / \mathrm{ha}$ for obtaining higher seed yield, nutrient content and uptake and available nutrients in soil after harvest in loamy sand soil of North Gujarat Agroclimatic conditions.

\section{Acknowledgements}

We are thankful to Agronomy Instructional farm, Sardarkrushinagar for providing resources and Directorate of research, S.D.A.U., along with C.P. College of agriculture for providing research facility and funding to conduct the trial.

\section{References}

Ameta, V., Chaplot, P. C. and Sumeriya, H. K. (2014). Response of elite mustard [Brassica juncea (L.) Czern and Coss] varieties to balanced fertilization and agrochemicals. Annals of Agri-Bio Research. 19 (1): 49-54.

Dawson, Y. K., Kishanrao, J. Z. K., Dixit, P. M. and Khatkar, R. (2009). Effect of nitrogen, phosphorus and sulphur fertilization on growth and yield of mustard (Brassica juncea). International Journal of Agricultural Sciences 5 (2): 396-398.

Fisher, R.A. (1950). Contribution to mathematical statistics. New York: Willey.

Jadav, N.J., Parmar, J.K., Gangwal, T.V. and Patel, M.V. (2016). Effect of phosphorus, sulphur and phosphate solubilizing bacteria on yield, nutrient uptake and soil fertility after harvest of mustard. An Asian Journal of Soil Science. 11 (2): 307-317.

Keivanrad, S. and Zandi, P. (2014). Effect of nitrogen levels on growth, yield and oil quality of Indian mustard grown under different plant densities. Cercetări Agronomice in Moldova. 1 (157): 81-95. Kishore, R., Dev, J., Singh, A. and Singh, S. 
S. (2014). Growth, yield, quality and nitrogen uptake of various genotypes of mustard (Brassica junceaL.) as influenced by varying nitrogen levels under late sown conditions in Eastern Uttar Pradesh. International Journal of Agricultural Sciences. 10 (1): 260-263.

Neha.,Dashora, L.N., Kaushik, M.K. and Upadhyay, B. (2014). Yield, nutrient content, uptake and quality of Indian mustard genotypes as influenced by sulphur under southern Rajasthan conditions. Annals of Agri-Bio Research. 19 (1): 81-84.

Om, H., Rana, K.S. and Ansari, M.A. (2013). Productivity and nutrient uptake of mustard (Brassica juncea) influenced by land configuration and residual and directly applied nutrients in mustard under limited moisture conditions. Indian Journal of Agricultural Sciences. 83 (9): 933-938.

Pachauri, R.K., Trivedi, S.K. and Kumar, Y. (2012). Effect of sulphur levels on growth, yield and quality of Indian mustard genotypes and their economics. Journal of Soils and Crops. 22 (2): 258263.

Parmar, R.M., Parmar, J.K. and Patel, M.K. (2011). Effect of nitrogen and sulphur on content and uptake of nutrient by mustard crop under the loamy sand soil of North Gujarat. International Journal of Agricultural Science. 7 (1): 103-106.

Rai, S., Singh, Y., Nath, T. and Rajput, B.S. (2014). Effect of various does and sources of sulphur in the growth and yield attributing trait of Indian mustard
[Brassica juncea(L.) Czern and Coss]. International Journal of Tropical Agriculture. 32 (1-2): 243-246.

Sah, D., Bohra, J. S. and Shukla, D. N. (2006). Effect of N, P and S on growth attributes of and nutrient uptake by Indian mustard [Brassica juncea $(\mathrm{L}$. Czern and Coss]. Crop Research (Hissar). 31 (1): 52-55.

Singh, R.K., Singh, A.K. and Kumar, R. (2010). Effect of fertility level on Nutrient uptake, Yield and Quality of Indian mustard [Brassica juncea $(\mathrm{L}$. Czern and Coss] varieties under late sown condition. Environment and Ecology. 28 (3A): 1764-1767.

Singh, S.B. and Thenua, O.V.S. (2016). Effects of phosphorus and sulphur fertilization on yield and NPS uptake by mustard [Brassica juncea(L.) Czern and Coss]. Progressive Research - An International Journal. 11 (1): 80-83.

Tripathi, M.K., Chaturvedi, S., Sukla, D.K. and Saini, S.K. (2011). Influence of integrated nutrient management on growth, yield and quality of Indian mustard [Brassica juncea $(\mathrm{L}$.) Czern and Coss] in Tarai region of Northern India. Journal of Crop and Weed. 7 (2): 104107.

Yadav, H.K., Thomas, T. and Khajuria, V. (2010). Effect of different levels of sulphur and biofertilizer on the yield of Indian mustard [Brassica juncea (L.) Czern and Coss] and soil properties. Journal of Agricultural Physics. 10: 6165.

\section{How to cite this article:}

Zalak Y. Chauhan, D. K. Patel and Komal Bhabhor. 2020. Effect of Nitrogen, Phosphorus and Sulphur on Yield, Nutrient Uptake and Soil Fertility after Harvest of Mustard (Brassica juncea L.). Int.J.Curr.Microbiol.App.Sci. 9(06): 3506-3512. doi: https://doi.org/10.20546/ijcmas.2020.906.412 